\title{
Soviet Library of Historical Research
}

$\mathrm{T}$ he Soviet Library of Historical Research was founded in Moscow in 1938. Similar libraries have been established in several of the U.S.S.R. republics. On the shelves of this library, which contains one and a half million volumes in all the principal languages of the world, are editions of historical works issued in the United States, Great Britain, France, and other countries, from the rise of printing to the present day. Particularly well represented are books on the history of the peoples of the U.S.S.R. A large number of rare and unique editions of the fifteenth, sixteenth, and seventeenth centuries are preserved in the library's storeroom.

By a special decree of the government, the Library of Historical Research is provided gratis with one copy of every book published in the U.S.S.R., but it also receives from abroad a considerable part of its historic and bibliographic materials. It has established a regular exchange of books with many libraries and institutions of learning in the United States, England, China, and other countries. Neither before nor during the war, however, has it suffered from lack of funds for its numerous subscriptions. One of its recent acquisitions is a large private collection of the admirable Elzevir editions published in Amsterdam at the end of the sixteenth and the beginning of the seventeenth centuries.

There are four spacious reading rooms at the library, each serving its own purpose-the general reading room, a special reading room for historical research, the U.S.S.R. history reading room, and a separate world history hall. There is also a room for Oriental history and a branch library for secondary school pupils.

During the brief period of its existence, the Library of Historical Research has served nearly a million and a half readers, to whom over four million books were issued. Ever since its inception, the number of readers has been constantly growing. In the current year attendance as well as the number of books drawn have reached the prewar level. In 1940 the library served 309,717 persons with $1,018,990$ books. In eight months of $1944,824,803$ books were given out to 247,267 readers.

The library is frequented by historians, college teachers, postgraduates, and students. There also are a large number of writers, journalists, theatre and film people, artists, and architects among the regular clients. The library staff has maintained a regular contact with readers in the ranks of the Red Army.

Not for a single day did the library cease work during the war. It was open even in the stern days when the Nazi hordes, having reached Moscow's gates, threatened to seize the capital.

Much of the work of the library's staff is devoted to the compilation of bibliographies of U.S.S.R. and world history. Several copious bibliographic works in the field of history appeared in Russia before the revolution of 1917. Most important among these are Historical Research of Russian Periodicals and Anthologies Issued in $1703-1802$ by A. N. Neustroev; V. I. Mezhov's Bibliography of Russian History 1800-1854 in three volumes; ten volumes of Bibliography of Works of Russian History 
(1855-1864) by P. and B. Lambin; and $A$ Guidebook to Russian Historical Literature $(1865-1876)$ by V. I. Mezhov, in eight volumes. These books cover Russian historical literature from the beginning of printing in Russia up to 1876 ; that is, a period of 175 years, and include some two hundred thousand works. Today the compilation of bibliographies of historical literature is regarded as an affair of national importance. In a comparatively brief period of time, the library staff listed ninety thousand editions. However, there is still a great deal of bibliographical work ahead for the historical works published after I 873 and particularly during the years following the revolution.

Historical Literature, a bulletin issued by the Library of Historical Research, plays an important role in popularizing books on Russian and world history in the U.S.S.R. The bulletin contains information on all new works on history published in the U.S.S.R. and abroad, and is a valuable guide 'to the ever-growing number of students in the Soviet Union.

Another phase of the library's activities is the compilation of indexes on various fields of historical research and major historical problems. At present, for example, the staff is working on indexes of historical literature on the Patriotic War of 1812 , on the history of the Middle Ages, and on the first volume of the history of the U.S.S.R., which covers books down to the twentieth century. A guide to bibliographies on Russian historical works was compiled recently. Work on a bibliographic index of Russian history books for secondary school teachers is now nearing completion. Simultaneously the library's staff is engaged in compiling a guide to literature on the history of the Slav people and historical works dealing with the Great Patriotic War against the German invaders. A voluminous guidebook to the books on the history of Moscow will be issued in 1947 on the occasion of the eight hundredth anniversary of the founding of Moscow.

The reference department supplies written and oral information to state and public institutions, as well as to individual readers desiring historical data.

At the beginning of the recent war the library set up two branches-one in an Army hospital and the other in the Kurskaya station of the Moscow underground. It was in the perilous days of November 194I, when the enemy threatened Moscow, that the branch in the underground station was opened. This, whose chief purpose it was to supply books to Moscovites taking cover from Nazi bombs, was a great success. Apart from issuing books, the librarians arranged lectures and talks and conducted discussions. The librarians also provided reading matter for the children.

Opened in December I94 I, the hospital branch of the library exists to this day. Convalescent men and officers are always asking for more materials on history. Readings and book discussions are organized for the patients. In their letters to the library, the soldier-patients express their gratitude to the staff for the large number of interesting books placed at their disposal.

Another branch has been set up by the library to supply books to secondary school pupils. With a daily attendance of from four to five hundred school children, it is extremely popular and is a great aid to the study of history in the schools. The branch recommends books, supplies historical data, arranges exhibits, and organizes historical essay competitions.

The activities of the Library of Historical Research are not confined to Moscow alone. Through an exchange system among Soviet libraries, history lovers and scholars of history living in the most remote parts of the Soviet Union may receive books from 
it through their local libraries.

When the enemy was approaching Moscow, the library's staff, helped by the citizens of Moscow, took all possible steps to preserve the collections. By then the most precious editions already had been transported to the interior of the country. A good part of the books, however, remained in the capital. During the enemy's raids, library workers took up posts on the roof and attics of the library to extinguish incendiaries dropped by Nazi bombers. Recently thirty-eight members of the library's staff were awarded the For Defence of
Moscow medal for their gallant services in those perilous days.

Today the Soviet people are happy in the knowledge that their great efforts and sacrifices were not in vain. The personnel of the Library of Historical Research, along with the libraries all over the Soviet Union, derive inspiration from the fact that their labor is highly valued by the government both in war and peace. Additional. proof of this is the considerable rise in salaries recently granted to all library workers, despite the great demands made by the war on the country's budget.

\section{Academic Status for University Librarians}

\section{(Continued from page 9)}

tember and ending in June, while librarians are on twelve-month appointments. For hours of work, vacations, and holidays, librarians are grouped with general administrative officers. This means a work week of thirty-nine hours, an annual vacation of one month, and all holidays observed by the university. Incidentally, analogous provisions govern the university's nonteaching research staff in various departments.

\section{Summary}

In summary, it is the conclusion of those who have given long study to library staff problems at the University of Illinois, first, that professional librarians, by the nature of their functions, definitely belong in the instructional and research group; second, by comparative standards of education and preparation, they qualify for inclusion with the teaching staff; and, third, there are numerous tangible and intangible advantages for librarians in holding an academic classification. With reference to the last point, the factor of staff morale is of primary significance. One can expect the best results from any organization only if its place is clearly understood and appreciated. The improved status of librarians at Illinois is certain to play a major part, as time goes on, in the development of a library staff with a high sense of professional pride and responsibility, conscious of the importance of its work, and receiving proper compensation and recognition for its contribution to the institution. 